\title{
PLANNING IN LUXEMBOURG: INNOVATION AND TRADITION UNDER ONE UMBRELLA?
}

\author{
Sebastian Hans (D), Kai Böhme \\ Spatial Foresight $\mathrm{GmbH}$ \\ 7, rue de Luxembourg, L-7330 Heisdorf: Luxembourg \\ sebastian.hans@spatialforesight.eu,kai.boehme@spatialforesight.eu
}

\begin{abstract}
For quite some while Luxembourg has seen an impressive socio-economic development, rendering spatial planning interesting. Although the spatial planning system in Luxembourg is relatively young, it is used to digest and to distribute the socio-economic growth and push for a more polycentric territorial structure. For this, policy makers have a range of instruments available. These include traditional but also many forward-thinking approaches, which give spatial planning in Luxembourg an innovative edge compared to other European countries. Among these forward-thinking approaches are e.g. national public participation processes, soft territorial cooperation or cross-border planning. Therefore, we argue in this article that supplementary to the traditional elements, spatial planning in Luxembourg has many innovative features, deserving more attention in the international planners' community. Indeed, policy makers from all around Europe can learn and capitalise from the Luxembourgish experiences.
\end{abstract}

Keywords: spatial planning, governance, Luxembourg, growth, innovation, participation, cross-border planning.

\section{Introduction}

Luxembourg has seen impressive socio-economic development over the past decades. The territorial development challenges coming with the high growth rates make the Luxembourgish spatial planning interesting. It relies on well-established strategies found elsewhere in Europe, but also implements forward-thinking approaches that defy comparison. We will showcase both, the traditional and innovative elements, their raisons d'être and argue why policy makers from across Europe can learn from the practices in Luxembourg. This text builds on the work conducted for the case study on the Luxembourgish spatial planning and governance system for the ESPON COMPASS project (ESPON 2018) and the work conducted for the national platform for urban politics (CIPU) ${ }^{1}$.

We will provide a short introduction to the Grand Duchy and important spatial trends. Then, we will highlight the specificities and challenges for spatial planning and governance. This showcases the system, underlying objectives and topics, which emphasises the challenges faced by the spatial planning system along with classic and innovative solutions.

\footnotetext{
${ }^{1}$ See: http://www.cipu.lu/index.php/base-documentaire.
} 


\section{The country of Luxembourg and spatial trends}

National policy makers often mention that the domestic context in Luxembourg is too specific and thus obstruct comparison with other countries. Still are not all countries and their developments unique in some way? Below we highlight a few specificities and prevailing aspects that render the challenges the Luxembourgish spatial planning system has to tackle specific. First, we present the socio-economic development and their spatial structure within the country before we introduce policy objectives and challenges to the spatial planning system.

Luxembourg is the second smallest country in the European Union. It is e.g. about five times larger $\left(2586 \mathrm{~km}^{2}\right)$ than the city of Warsaw but with about a third of Warsaw's inhabitants (602 000 in 2018) (STATEC 2018b). The country is about $80 \mathrm{~km}$ by $60 \mathrm{~km}$, with the capital and major centres in the southern part. Land is a limited resource in Luxembourg.

Between 2010 and 2018, the number of inhabitants has increased significantly. The demographic growth is explained by people moving in. On average, the country receives 13000 new residents per year. Over the past eighteen years the population has increased by some $40 \%$ (STATEC 2018b). In future, the population of Luxembourg is expected to increase from currently 0.6 million to 1.1 million inhabitants by 2050 or 2060 respectively (STATEC 2017).

Many foreigners and commuters are attracted by the economic development. Luxembourg's GDP is well known to be far higher than the European average. This attracts many companies, resulting in an ever-increasing number of jobs in the country, affecting the ratio between residents and jobs. Of four residents, three are economically active (STATEC 2018b). However, many employees do not live in the country and some $40 \%$ are cross-border commuters from France, Belgium or Germany (STATEC 2018b).

Population and employment distribution and growth is unbalanced. Luxembourg City houses about one fifth of the population (STATEC 2018b). Every third person in the country lives in one of the four largest cities; Luxembourg City, Esch-sur-Alzette, Differdange or Dudelange (STATEC 2018b). These are all in the centre and south of the country. The population is a little more equally distributed than employment for which the capital area prevails. $55 \%$ of all employment is in Luxembourg City and surrounding municipalities, attracting commuters from within and outside the country (Decoville \& Feltgen 2018).

To address population growth, policy makers also want to implement a more polycentric territorial structure, allowing for more territorially balanced growth and relieving infrastructure systems across the country (MDDI 2016). Thus, spatial planning in Luxembourg has a twofold objective: (A) structuring existing territorial elements and (B) managing and actively shaping the socio-economic growth of the country. However, there are obstacles to national approaches.

Because of its geography and its growth, Luxembourg repeatedly reaches its limits. Development in the country has made considerable progress. Rapidly increasing numbers of inhabitants and economic growth are also taking their toll. Growth requires land, which is a scarce resource in the country. In the debate on spatial planning, decision makers realised that the small size of the country is a bottleneck. Therefore, Luxembourg has far reaching experience in political integration with its neighbours. This is because of historical links but also because of an early awareness that cooperation is a must and not a luxury. The large increase of cross-border workers is thus only one more recent symptom of many versatile cross-border relations. Long-lasting cooperation has also impacted the spatial planning system, with national strategies considering cross-border relations and joint planning efforts. 


\section{Spatial planning and governance}

Strong growth and expectations towards spatial planning put high pressure on policy makers. This raises the question what instruments do planners have at hand to fulfil these expectations and tasks? The following paragraphs will elaborate on the layout and characteristics of the planning instruments system (Fig. 1).

Through spatial planning, Luxembourg wants to mitigate negative effects and shape growth. The national discourse on spatial planning is influenced strongly with discussions how to engage with demographic and economic growth. In a country where land is limited, public discourse about growth has quickly transformed into debates on the future quality of life and the role of spatial planning and architecture. This has led to the aspiration of mitigating negative externalities and actively shaping the country's growth. The spatial planning system is measured by the highest standards.

Luxembourg's current spatial planning and governance system is quite young. The existing setting for structuring Luxembourg has been introduced incrementally since 2003. The instruments have been significantly inspired by the European discourse on spatial planning, summarised in the European Spatial Development Perspective (ESDP) and the Territorial Agenda (Ministère de l'Intérieur 2003; Eser 2011; Eser \& Böhme 2015). Since 2003, the system has been recurrently updated, changed and improved.

There are two main spatial planning levels. These involve state ministries at the national level with national strategic instruments (Table 1 ) and municipalities at the local level with municipal land-use plans (Table 2). The parties sometimes have different aspirations for spatial planning. This is a well-known conflict of local development versus the aspiration of national planning (Hesse 2013). The state has therefore adopted a direct role in planning and sometimes implementing national projects, overruling local interests.

The national level uses strategic and regulatory instruments (Table 1). The purpose of these instruments is to define development objectives for the future territorial structure of the country. These instruments also address fundamental questions such as how growth should be dealt with and what shall be the structure of the territory. The national level also features a range of regulatory tools (PDS). These should link to the strategic tools and support their implementation. Today, the regulatory tools mainly appropriate land for future national developments, such as large-scale housing projects.

At local level, the instruments structure land-use within municipalities (Table 2). The country mainly has tiny municipalities. In 2018, Luxembourg has 102 , but the number is steadily decreasing due to municipal mergers. Nevertheless, 72 of the 102 had less than 5000 inhabitants and only 10 had more than 10000 inhabitants (STATEC 2018a). The PAG and PAP represent the only effective land-use planning instruments. To ensure significance of the other tools, municipalities developing land-use plans should respect the higher-ranking planning instruments. There are also 'Conventions', which are an intermediate tool bringing together municipalities, possibly with the state (CIPU 2018a). These were originally intended to achieve strategic objectives laid out in the PDAT but they can also be used for strategic cooperation between municipalities. 

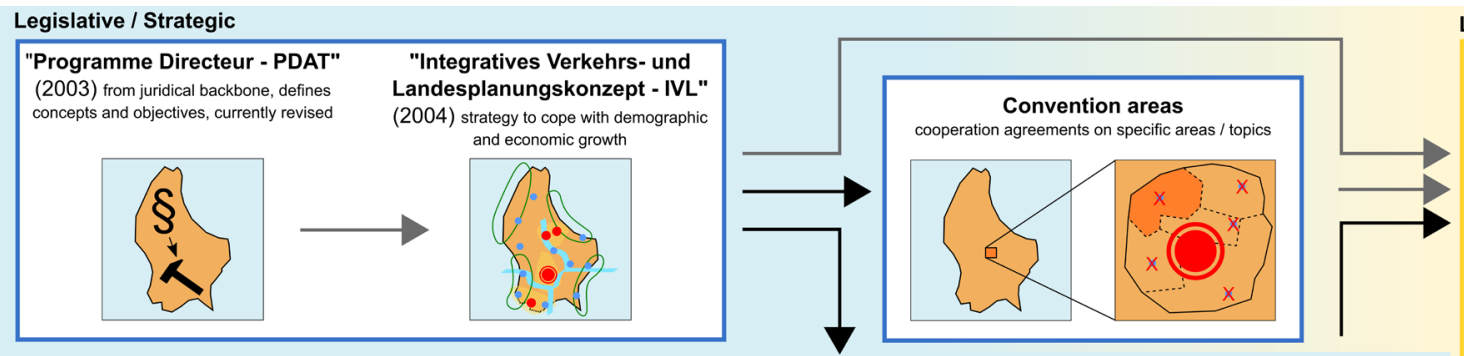

"Schéma du Développement Territorial de la Grande Région - SDTGR" (since 2009) exchange in

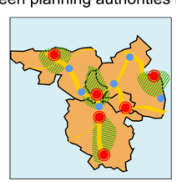

"Grenzüberschreitendes Entwicklungskonzept Oberes Moseltal - EOM" (2018) bilateral guideline to strengthen functional links

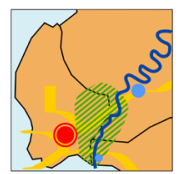

Strategic / Cross-border

"Plans directeurs sectoriels - PDS" (2008-18)

executive plans, implementing "Programme Directeur" and "IVL". The plans are expected to be adopted by the end of 2018. After revision, the instrument will reserve land for projects of national priority and thus contributing to the achievements of the national policy targets.

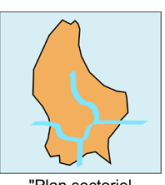

"Plan sectoriel
TRANSPORTS"

"Plans d'occupation du sol - POS" (e.g. airport, military sites)

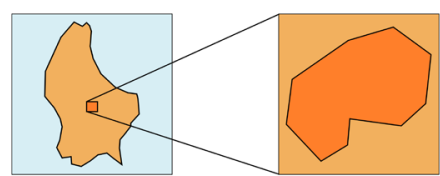

Reglementary level

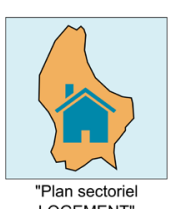

"Plan sectoriel
LOGEMENT"

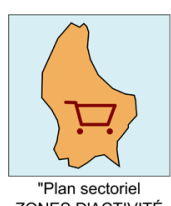

ECONOMIQUES" regulation of land use in frequently flooded areas

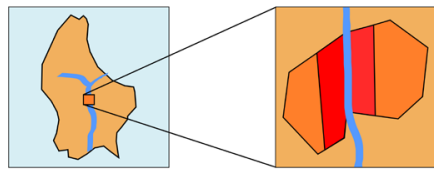

"Plan d'aménagement général - PAG" municipal land use plans, across different sectors, strategic pre-study

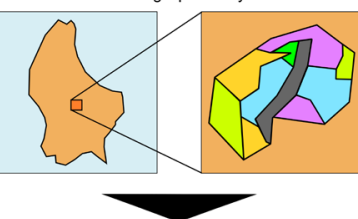

"Plan d'aménagement particulier

$$
\text { -PAP" }
$$

Fr types of land-use and individual parcels, must be in line with PAG

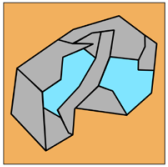

Ministry of Energy and Spatial Planning

Ministry of Interior

Direct/statutory influence

Indirectnon-statutory influence

Figure 1. Main instruments and links of Luxembourg's spatial planning system. Source: own elaboration, based on work conducted for ESPON (2018). 
Table 1. National spatial planning instruments in Luxembourg

\begin{tabular}{|c|c|}
\hline Instrument name & Instrument characteristics \\
\hline $\begin{array}{l}\text { PDAT } \\
\text { (French: "Programme directeur } \\
\text { d'aménagement du territoire", } \\
\text { English: Master programme } \\
\text { for spatial planning) }\end{array}$ & $\begin{array}{l}\text { The PDAT is the underlying strategic spatial planning concept and strategy, } \\
\text { including objectives and visions for the territorial development of the country. } \\
\text { This is inspired by the ESDP and is the primary strategic planning instrument. } \\
\text { Published in 2003, the PDAT is an overarching strategic framework for spatial } \\
\text { planning. It summarises development objectives for and through different } \\
\text { policy fields. The PDAT can include reflections on territorial structures } \\
\text { and functional integrations across the country. It also addresses policies } \\
\text { for administering growth and reflects on prospective development } \\
\text { of the country. In short, it is a 'one-size-fits-all' multi-sector planning } \\
\text { document. Originally, it was planned to be implemented through the PDS } \\
\text { (see below, MDDI 2018d). }\end{array}$ \\
\hline $\begin{array}{l}\text { IVL } \\
\text { (German: "Integratives } \\
\text { Verkehrs-und } \\
\text { Landesentwicklungskonzept", } \\
\text { English: Integrated traffic } \\
\text { and territorial development } \\
\text { concept) }\end{array}$ & $\begin{array}{l}\text { The IVL is a national strategic document addressing growth related challenges } \\
\text { to spatial planning in depth. }\end{array}$ \\
\hline $\begin{array}{l}\text { SDTGR } \\
\text { (French: "Schéma de } \\
\text { Développement Territorial de } \\
\text { la Grande Région", English: } \\
\text { Territorial development } \\
\text { concept for the Greater } \\
\text { Region) }\end{array}$ & $\begin{array}{l}\text { SDTGR is a cross-border multilateral development concept that is currently } \\
\text { under elaboration. Its objective is to implement a cross-border polycentric } \\
\text { metropolitan region at the level of the Greater Region. }\end{array}$ \\
\hline $\begin{array}{l}\text { EOM } \\
\text { (German: } \\
\text { "Grenzüberschreitendes } \\
\text { Entwicklungskonzept Oberes } \\
\text { Moseltal", English: Cross- } \\
\text { border development concept } \\
\text { Upper Moselle Valley) }\end{array}$ & $\begin{array}{l}\text { EOM is a cross-border development strategy to sustainably develop } \\
\text { the Upper Moselle valley. }\end{array}$ \\
\hline $\begin{array}{l}\text { PDS } \\
\text { (French: "Plans directeur } \\
\text { sectorial", English: Directive } \\
\text { sector plans) }\end{array}$ & $\begin{array}{l}\text { PDS are national level directive plans. Their objective is to implement } \\
\text { the PDAT through four sector approaches, namely transport, housing, } \\
\text { economic activity zones and landscapes. These sector plans were developed } \\
\text { to include the relevant ministries in spatial planning but had little cross- } \\
\text { fertilisation between the sectors. This has led to incompatibilities between } \\
\text { the plans, not least conflicting development objectives. Implementation was } \\
\text { halted in 2014, as they would impair fundamental citizen rights and interfere } \\
\text { with municipal autonomy. This also means that the } 2003 \text { PDAT thereby } \\
\text { lost its statutory condition to the municipal land-use plans. The PDS were } \\
\text { consequentially revised and are again at the final implementation step } \\
\text { (expected to be adopted by the parliament in near future), though only } \\
\text { as a sector instrument to appropriate or preserve land. }\end{array}$ \\
\hline $\begin{array}{l}\text { POS } \\
\text { (French: "Plans d'occupation } \\
\text { du sol", English: Land use } \\
\text { plans ) }\end{array}$ & $\begin{array}{l}\text { POS includes detailed provisions for areas of national importance such } \\
\text { as airports and military sites. }\end{array}$ \\
\hline $\begin{array}{l}\text { Plan d'aménagement partiel } \\
\text { (English: Partial land-use plan) }\end{array}$ & $\begin{array}{l}\text { Plan d'aménagement partiel is a plan including urban requirements for areas } \\
\text { that are frequently flooded. }\end{array}$ \\
\hline
\end{tabular}

Source: own elaboration. 
Table. 2. Local spatial planning instruments in Luxembourg

\begin{tabular}{|l|l|}
\hline \multicolumn{1}{|c|}{ Instrument name } & \multicolumn{1}{c|}{ Instrument characteristics } \\
\hline $\begin{array}{l}\text { Agreements on convention } \\
\text { areas }\end{array}$ & $\begin{array}{l}\text { As consequence of fragmentation, many municipalities in Luxembourg } \\
\text { have small administrations and are often too understaffed to address } \\
\text { aspects beyond their daily business. Convention areas are straightforward } \\
\text { contractual agreements between several municipalities and/or the state } \\
\text { that cooperate under the 'convention tool'. This approach enables players } \\
\text { to engage in soft territorial cooperation across policy topics and governance } \\
\text { levels (CIPU 2018a). Partners in convention decide on all aspects, including } \\
\text { the governance structure, topics for cooperation, instruments to be used } \\
\text { and monitoring processes. Conventions implement national objectives } \\
\text { of the PDAT when actions of single municipalities are not sufficient. }\end{array}$ \\
\hline $\begin{array}{l}\text { PAG } \\
\text { général", English: General } \\
\text { land-use plan) }\end{array}$ & $\begin{array}{l}\text { PAG are the local land-use plans drafted individually for each municipality. } \\
\text { This is the equivalent of a zoning plan where municipalities lay down zones } \\
\text { and detail preferential uses. PAG are created by municipalities and only } \\
\text { reviewed by the state. This represents the central dilemma of the planning } \\
\text { system: because with their land-use plans, municipalities possess the only } \\
\text { executive land-use planning instrument, leaving the state unarmed. }\end{array}$ \\
\hline $\begin{array}{l}\text { PAP } \\
\text { (French: "Plan d'aménagement } \\
\text { particulier", English: Specific } \\
\text { land-use plan) }\end{array}$ & $\begin{array}{l}\text { PAP are plans for individual parcels of land. These address specific } \\
\text { characteristics such as building type, layout of public spaces, building } \\
\text { height, roof form for plots, zones or smaller districts within a municipal PAG. }\end{array}$ \\
\hline
\end{tabular}

Source: own elaboration.

The system includes two fundamentally different approaches to planning. On the one hand, the state ensures that land for large-scale developments is reserved or appropriated. These developments contribute to national strategic objectives. On the other hand, municipalities benefit from strong autonomy in planning. When planning beyond the large-scale state projects, municipal planners can get inspiration from the national strategic documents, allowing for rather indirect connections to national objectives. This means that despite the existence of strategic national plans, municipalities are not yet legally required to follow their provisions.

\section{Core topics for spatial planning in Luxembourg}

Beyond the structure of the spatial planning system are several topics that stand at its very centre. These are tailor-made responses and pathways based on the local specificities and challenges which significantly shape spatial planning within the country. These plans for decentralisation from Luxembourg City, national public participation for the PDAT and cross-border coordination of strategic planning documents are explained below.

\section{Polycentric territorial structure}

Luxembourg is highly centralised, with Luxembourg City having the highest concentration of jobs, housing and businesses. Scarce housing as well as traffic congestion around the capital and across the entire country are the consequence. The national body for spatial planning uses therefore the polycentric model as territorial vision. This aims to distribute future growth across the country in a more balanced manner which should decongest the capital area and support new regional 
growth poles (Decoville \& Klein 2014). CDA (French: "Centres de développement et d'attractions", English: Development and attraction centres) is a classification of cities within a national hierarchy. By developing CDAs, polycentricity will be strengthened (Ministère de l'Intérieur 2003). But what does this mean in practice?

The country intends to break the current spatial structure. How does one transform a village into a city? Developing $\mathrm{CDAs}^{2}$ should use highly concentrated developments, strengthening their urban character and limiting urban sprawl. This is important to the spatial planning discourse in Luxembourg as the division of people and jobs between CDAs is expected to introduce many improvements and sustain the quality of life for residents. Developing these intermediate and regional centres within the country requires significant effort. Luxembourg City is the superior CDA, but the 2003 PDAT mentions two intermediate and twelve regional CDAs. By developing these, Luxembourg is actively increasing the number of cities in the country. In light of this objective, there is a need for stronger inter-municipal cooperation.

\section{Luxembourg participation process to revise planning strategy}

The PDAT defining future development objectives for the country is currently under revision. This offers several opportunities: contemporary topics can be included and addressed through the PDAT. The body in charge of spatial planning has used this opportunity to organise a national participation process which has run for several months and was concluded in 2018. It was designed for participation by regular citizens as well as cross-border commuters, not living but working in Luxembourg, thus including a range of population groups. This is the only national participation process for spatial planning strategic objectives in the European Union.

The participation process allowed participants to become involved in spatial planning. It broke down the sometimes-complex subject of spatial planning for citizens involved creating a geographic and thematic division. Geographically, regional 'laboratories' were held in four regions (Nord, Centre, South, East). These were complemented by three cross-border groups from Belgium, France and Germany (MDDI 2018c, 2018d). Each laboratory consisted of about 50 participants, subdivided into five thematic groups. In addition, a parallel ministerial working group focussed on the governance of the new PDAT. The results of the participation process will feed into drafting the new PDAT from the end of 2019. Despite having little experience with such innovative and strategic participation processes, Luxembourg shows that they are possible at the national level.

\section{Luxembourg cross-border thinking for spatial planning}

Luxembourg is a member of the Greater Region ${ }^{3}$ covering Luxembourg and the neighbouring regions of Belgium, France and Germany. It's a supra-regional institutionalised cooperation network for exchange and coordination between decision makers and practitioners. This cooperation has become crucial in the light of many cross-border links between members. Rather than solving issues through bilateral agreements, the Greater Region is a cooperation platform on political and technical aspects. Members also coordinate spatial planning. It has become a habit of Luxembourg authorities to consult and reconcile on territorial developments with neighbours at all levels (MDDI 2016). The following few paragraphs present implementation of the different initiatives involving cross-border cooperation in spatial planning - from the national to the individual citizen level.

\footnotetext{
${ }^{2}$ Due to their morphology, many CDAs today would classify in other member states of the European Union only as villages and not as urban centres.

${ }^{3}$ See: http://www.granderegion.net/.
} 
Greater Region members are developing a cross-border territorial strategy. Cross-border coordination for spatial planning has a considerable history in the Greater Region. Since 1971, the structure has been used for formal and informal coordination also for spatial planning. Several objectives were since defined to strengthen inter-institutional cooperation formulated in short and long term objectives. These are inter alia the development a strategic operational vision and scenarios for the Greater Region for the 2050 time horizon (STDGR). Outputs of this international process will be applied by Greater Region members as superordinate objectives, inspiring domestic spatial planning strategies (MDDI 2018b).

Luxembourg also coordinates planning with its neighbours bilaterally. Some territories require geographically limited approaches to planning as they are geographically confined. This includes the Upper Moselle valley, which covers much of the Luxembourg Germany border. EOM ${ }^{4}$ (Cross-border development concept Upper Moselle Valley) is a lower level cooperation approach to spatial planning. The long-term objective is to increase functional integration across borders to maintain this historic cultural landscape while not impeding its socio-economic development (MDDI 2018a).

Locally, there is institutionalised cross-border cooperation. The large-scale project of Belval in the southern fringe of Luxembourg is a brownfield development and part of the country's decentralisation programme. On the border with France, Belval has become home of the University of Luxembourg and other important research institutions and is, today, the economic motor of the South. During 2012, the EGTC (European Grouping of Territorial Cooperation) 'Alzette-Belval' was founded as a cross-border cooperation institution. It was created for the purpose of harmonising and stabilising cross-border relations of citizens and decision makers in the border area of Belval ensuring harmonious and joint development (Becker 2016; Alzette Belval GECT 2018). The country is also comfortable with using European instruments to cooperate across borders (Zillmer et al. 2018a, 2018b).

Non-residents participated in updating the planning strategy. Apart from the broad national process to update the PDAT, non-residents also participate. Three laboratories, for Belgium, France and Germany, involved 45 persons working in Luxembourg. National participation was organised through workshops enabling participation through co-creation, while the cross-border group was involved in a consultative process. This has provided cross-border commuters with the possibility of conveying their territorial needs and wishes for the future development of the country (MDD, 2018c, 2018d). Including non-nationals in a national participation process in Europe was previously unknown and acknowledges the role of cross-border commuters for the country.

\section{Spatial planning in Luxembourg: between tradition and innovation}

Describing the major driving forces, challenges and specificities offers some insights on the current trends and topics for spatial planning in the Grand Duchy. What else can we note about the country and what lessons can we draw from the Luxembourg case? Based on the previous descriptions, the following paragraphs will elaborate on the planning practices. Spatial planning in Luxembourg is practiced through top-down approaches but also through innovations found in the latest EU strategies. This renders the system traditional but also modern. To support our argument, we will introduce the elements and approaches that we consider as traditional and modern.

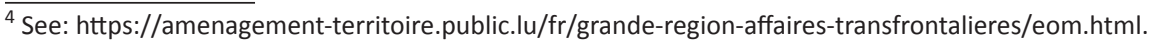




\section{Tradition}

Despite the youth of the Luxembourg spatial planning system, there are several traditional elements. These are the sector plans (PDS), the large-scale and top-down planning projects as well as strong municipal autonomy.

The PDS have a classical understanding of planning and structuring territory based on national development objectives. Implementing the 2003 PDAT involved introducing four PDS on housing, transport, economic zones and landscape. This is necessary for the state to acquire land to implement large-scale projects across the country. Such top-down projects (i.e. French: "Projets d'envergure", English: Large projects) are the nation's contribution to PDAT objectives.

Luxembourg is changing fast, not only in terms of economics and demography but also the built environment. During the past 20 years there have been many large-scale projects with the state or one of its institutions taking a pro-active role in planning. These projects sometimes challenge the structured planning approach and decentralisation objectives of the state. Examples are 'Belval', the never-ending expansion of 'Kirchberg' (CIPU 2018b), 'Ban de Gasperich', 'NeiSchmelz' (CIPU 2018d), the 'Nordstad' project, 'Wunne mat der Wooltz' (CIPU 2018c) and 'Elmen' to name just a few. The practice of planning top-down through large-scale projects is maybe a symptom of the development the country. To keep pace, spatial planning is forced into taking big steps. These projects are often seen as overruling local interests even though local autonomy is strong.

Municipal autonomy in land-use planning remains undisputed. Similar to other European countries, municipalities in Luxembourg control the only effective land-use planning instrument, the PAG. Effective statutory links to the primary national instruments, sector plans or the PDAT were not yet effective at the time of the analysis. This provides municipalities with a high level of independence from national objectives for zoning and land-use planning.

These aspects mean parts of the spatial planning system are traditional. Despite tradition being recognised as providing stability in spatial planning environments, it is not always easy to work with. An example is the revision of the sector plans, that are again in their final approval phase after being halted in 2014. In hierarchical systems, strategies are implemented by instruments and the actions of spatial planning instruments should be aligned with strategy objectives. In Luxembourg, it works the other way around. At least for the revised sector plans (PDS) where the strategy dates back to 2003 (PDAT). Meanwhile, a remake of this strategy is at full speed, and should become effective in 2020. So, when the instrument becomes effective, its underlying strategy will have just expired. Future municipal land-use plans (PAG) however then have to link to the updated strategy (PDAT post-2020). The crucial question is why municipal planning must respect provisions of new strategies after 2020 (new PDAT) and national planning (PDS) not.

\section{Modernity}

The system also features a range of modern aspects that we will introduce. These are the PDAT and the national participatory approach, the convention instrument and the cross-border reconciliation in spatial planning.

The PDAT is the modern counterpart to the PDS, thematically and conceptually. It is currently fit for the future with the inputs of a wide participation process, ensuring it is updated to structure developments across the country post-2020. The new version will become influential for future municipality land-use plans, allowing for cross-sector fertilisation from the strategic national level down to the municipalities. The PDAT is thus directly inspired by the ESDP, including across vertical and horizontal policy objectives. The participation process for creating the PDAT is also innovative 
involving not only a large number of residents but also non-nationals. Many objectives of the future PDAT can only be implemented through cooperation between several municipalities who control the only effective land-use instrument.

Conventions in Luxembourg illustrate a forward thinking planning approach. Conventions are inter-municipal cooperation structures for strategic spatial planning through soft and informal approaches. They enable local cooperation focussing on local interests and development objectives in exchanges with national stakeholders. This highlights another innovative component of the instrument, conventions bring together municipalities and the state. One of their outputs is thus vertical integration across governance levels. In spite of the great flexibility, the tool was not picked up as initially expected. Therefore a participation process with municipalities and state players was initiated to draw further conclusions on the future perspectives of the instrument (Faber et al. 2018). The current debate on restructuring the policy setting around conventions proposes even further loosening of cooperation structures. A convention or other structure for municipal cooperation can only be implemented after a successful trial period.

The habit of cross-border coordination of spatial planning is another innovation. As described above, Luxembourg coordinates spatial planning across several levels with its neighbours. The country therefore uses its own governance structures, the Greater Region or bilateral exchange structures as well as European instruments. Because of the long history and various approaches, Luxembourg spatial planners are at ease with cross-border spatial planning coordination.

\section{Traditional and innovative approaches under one umbrella?}

The spatial planning system in Luxembourg provides a broad spectrum of instruments. These were developed in different governmental terms addressing different policy priorities and aspirations for spatial planning. It is therefore not surprising that instruments follow different schools of thought. Top-down approaches of the soon-to-be former PDAT, in conjunction with the corresponding PDS, and municipal autonomy draw a classical picture of how territory is structured. Today however, the understanding of the role of these classical instruments has changed. At the same time, the country follows new paths with the revised PDAT, the soft territorial development instrument of conventions and cross-border coordination. Traditional and modern planning coexist in Luxembourg and work in parallel (Fig. 2). Overall, this allows spatial planners to choose from a range of different tools increasing flexibility and adaptivity of the spatial planning system.

\section{Conclusions}

Luxembourg's development defies comparison, in terms of economics and demographics. Policy makers want to use spatial planning as an instrument to digest and distribute growth and also to implement a new territorial structure. These are high aspirations that have resulted in the emergence of various, innovative spatial planning approaches. As a result, Luxembourgish policy makers can use a spectrum of tools, ranging from well-known regulative instruments such as sector plans or top-down projects to innovative and new planning techniques and approaches such as PDAT and cross-border coordination. These traditional and innovative spatial planning approaches co-exist side-by-side. The innovative elements of the system show that Luxembourg is ahead in the European debate for implementing and testing new and innovative practices in spatial planning. 
As it is frequently overlooked, spatial planning in Luxembourg has a wallflower-image in Europe. Policy makers and practitioners can however learn from Luxembourg practices. Still waters run deep.

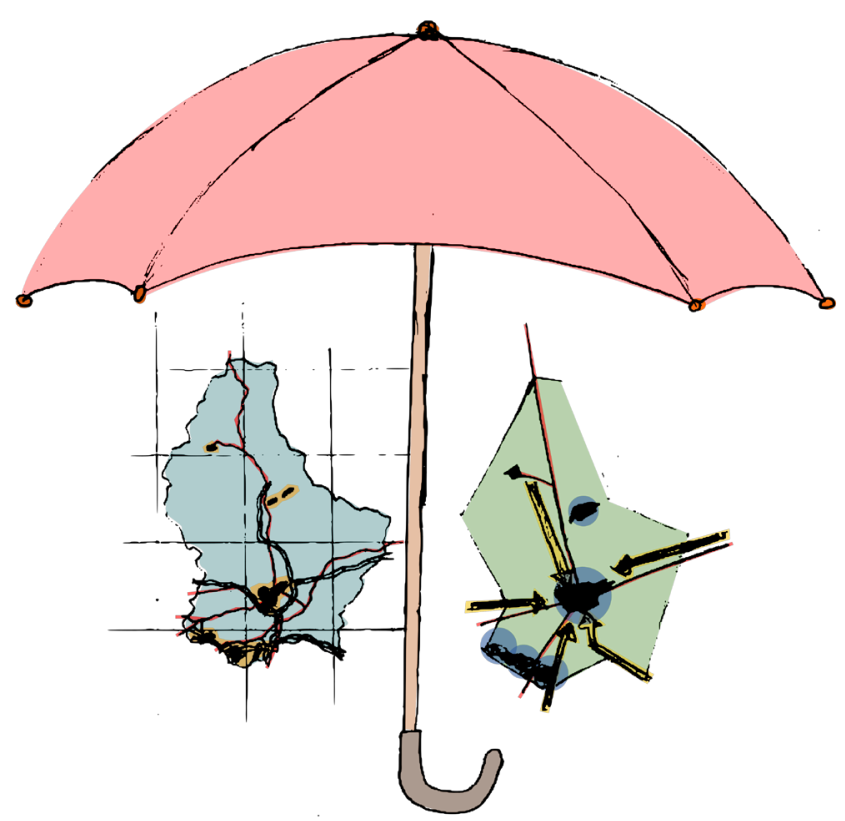

Figure 2. Luxembourgish spatial planning system as umbrella concept Source: own elaboration.

\section{References}

Alzette Belval GECT, 2018. Le GECT Alzette Belval? De la volonté commune à la création d'un GECT.

Becker T., 2016. Les rapports ville-université et la gouvernance: quelles leçons tirer 15 ans après le début du projet Esch-Belval? [in:] J. Dagnies (ed.) Bâtir Des Villes Nouvelles! Réinventer La Ville Pour Faire Croître La Qualité de Vie et Soutenir Le Développement Humain. Actes Du Colloque de Louvain-LaNeuve Du 23 Octobre 2015. CEPESS, pp. 148-154.

CIPU, 2018a. Conventions of territorial cooperation. Instrument enhancing inter-municipal and multilevel cooperation.

CIPU, 2018b. Development of housing withing the "Kirchberg" district in the city of Luxembourg. Lagrescale housing development in a business district.

CIPU, 2018c. Master plan "Wunne mat der Wooltz" in Wiltz. Large-scale industrial conversion project.

CIPU, 2018d. New district NeiSchmelz in Dudelange. Conversion of an industrial brownfield.

Decoville A., Feltgen V., 2018. Diagnostic du développement territorial.

Decoville A., Klein O., 2014. The Limits of Polycentrism at the City-regional Scale: The case of Luxembourg. European Journal of Spatial Development, vol. 1.

Eser T., 2011. Europäische Union, Regionalpolitik und Raumentwicklungspolitik - Ein Überblick, in: Chilla, T., Schulz, C. (Eds.), Raumordnung in Luxemburg. Guy Binsfeld, Luxemburg, pp. 276-295.

Eser T., Böhme, K., 2015. Coordination mechanisms for Territorial Cohesion - Cases of Europe and Luxembourg (Forschungsberichte der ARL), Koordination raumwirksamer Politik. Mehr Effizienz und Wirksamkeit von Politik durch abgestimmte Arbeitsteilung. Akademie für Raumforschung und Landesplanung, Hannover. 
ESPON, 2018. COMPASS - Comparative Analysis of Territorial Governance and Spatial Planning Systems in Europe - Final Report. Luxembourg.

Eurostat, 2018. Statistics explained. National accounts and GDP. Developments in GDP in the EU: growth since 2013.

Faber L., Sauerhöfer M., Böhme K., Hans S., 2018. Perspektiven der Konventionsgebiete als Instrumente der interkommunalen Kooperation. Ministerium für nachhaltige Enwicklung und Infrastrukturen, Luxemburg.

Gouvernement du Grand-Duché de Luxembourg, 2017. Luxembourg GDP in constant growth. Luxembourg's economy is expected to continue growing by more than $4 \%$ over the next two years.

Hesse M., 2013. Das Kirchberg-Syndrom: große Projekte im kleinen Land - Bauen und Planen in Luxemburg. disP, vol. 192, pp. 14-28.

MDDI, 2016. Wéi e qualitative Wuesstem fir eist Land? Landesplanung fir eng nohalteg Zukunft. Présentation dans le cadre de la table ronde politique le 10 novembre 2016.

MDDI, 2018a. Grande Région et Affaires transfrontalières. Grenzüberschreitendes Entwicklungskonzept Oberes Moseltal (EOM).

MDDI, 2018b. Grande Région et Affaires transfrontalières. Interreg SDTGR / REKGR.

MDDI, 2018c. Stratégies territoriales. notrefuturterritoire.lu. Processus participatif de refonte du PDAT.

MDDI, 2018d. Stratégies territoriales. Notre-FuturTerritoire.lu. Refonte Programme directeur d'aménagement du territoire.

Ministère de l'Intérieur, 2003. Programme Directeur d'Aménagement du Territoire.

STATEC, 2017. Projections de l'économie et de la population: l'avenir est ouvert.

STATEC, 2018a. Population par canton et commune 1821-2018.

STATEC, 2018b. Recensement de la population.

Zillmer S., Hans S., Lüer C., Montán A., Hsiung C.-H., Le Moglie P., Gnetti V., 2018a. EGTC Good Practice Booklet. European Committee of the Regions, Brussels.

Zillmer S., Hans S., Lüer C., Montán A., 2018b. EGTC monitoring report 2017. European Committee of the Regions, Brussels. 